University of Nebraska - Lincoln

DigitalCommons@University of Nebraska - Lincoln

January 2000

\title{
Remote Monitoring of Selected Ground-Water Dominated Lakes in the Nebraska Sand Hills
}

David C. Gosselin

University of Nebraska - Lincoln, dgosselin2@unl.edu

Donald C. Rundquist

University of Nebraska - Lincoln, drundquist1@unl.edu

Stuart K. McFeeters

University of Nebraska - Lincoln

Follow this and additional works at: https://digitalcommons.unl.edu/natrespapers

Part of the Natural Resources and Conservation Commons

Gosselin, David C.; Rundquist, Donald C.; and McFeeters, Stuart K., "Remote Monitoring of Selected Ground-Water Dominated Lakes in the Nebraska Sand Hills" (2000). Papers in Natural Resources. 132. https://digitalcommons.unl.edu/natrespapers/132

This Article is brought to you for free and open access by the Natural Resources, School of at DigitalCommons@University of Nebraska - Lincoln. It has been accepted for inclusion in Papers in Natural Resources by an authorized administrator of DigitalCommons@University of Nebraska - Lincoln. 


\title{
Remote Monitoring of Selected Ground-Water Dominated Lakes in the Nebraska Sand Hills
}

\author{
David C. Gosselin, Donald C. Rundquist, and Stuart K. McFeeters \\ Center for Advanced Land Management and Information Technologies \\ School of Natural Resource Sciences and Conservation and Survey Division \\ Institute of Agriculture and Natural Resources, 113 Nebraska Hall \\ University of Nebraska-Lincoln, Lincoln, Nebraska 68588-0517 \\ Corresponding author: D. Gosselin, email: dgosselin2@unl.edu
}

\begin{abstract}
:
The Landsat-Multispectral Scanner (MSS) data were used to measure lake area fluctuations (1972-1989) for 130 groundwater dominated lakes in the Western Lakes Region of the Nebraska Sand Hills. In general, the pattern shown in lake area hydrographs was similar to that for in-situ lake elevations. Insitu lake-elevation data verify that remote monitoring of surface-area fluctuations, even at relatively coarse spatial resolution, is not only practical and useful, but also it elucidates the hydrologic characteristics of groundwater-dominated lakes of the Sand Hills. The apparent differences in behavior between lakes in the northern and southern portions of the study area may be related to both their location in the regional ground water system and the substantial local hydrologic complexity.
\end{abstract}

Keywords: remote sensing, time series analysis, Landsat Multispectral Scanner, surface water hydrology, Sand Hills Lakes, wet lands.)

\section{Introduction}

Remote sensing is a documented tool for monitoring and analyzing inland aquatic environments (Work and Gilmer, 1976; Gilmer et al., 1980; Rundquist et al., 1987; Bobba et al., 1992; Gitelson et al., 1993; Yacobi et al., 1995). Satellite data allow one to obtain information about the number, spatial distribution, size, productivity, and, in some cases, depth of inland waters. The Landsat Multispectral Scanner (MSS), in operation between 1972 and 1993, provides researchers with a potentially unique historical data archive that can be used to examine surface water resources where no other hydrologic data exist. It may be possible to use MSS data for comparing the impacts of long-term climate change with natural seasonal variations.
The objectives of this paper are to: (1) examine the practical utility of archived digital coarse resolution Landsat-MSS data for investigating the seasonal and/or interannual patterns of lake-size variability; and (2) determine whether the measured fluctuations allow one to make meaningful inferences about the hydrologic characteristics of ground-water dominated lakes. To accomplish these objectives we examined historical satellite data and hydrologic records.

\section{Study Area}

The Nebraska Sand Hills, encompassing nearly $50,000 \mathrm{~km}^{2}$ or about one-fourth of the state, contain an estimated $450 \mathrm{~km}^{2}$ of shallow lakes and ponds, 260 $\mathrm{km}^{2}$ of marsh and $4,500 \mathrm{~km}^{2}$ of subirrigated meadows (Rundquist, 1983). These lakes and wetlands, which exist in sharp contrast to the sparsely vegetated uplands, are the result of a dynamic interaction among climatic, hydrologic, chemical, and biological processes. Underlying the region is 500 to 1000 feet of geologic material that comprises the northern High Plains aquifer. Water-dominated landscape features occur where this vast ground water reservoir intersects the low-lying, flat valley floors. Its myriad of wetlands make the Sand Hills, which provide habitat for over 300 bird species, the second most productive waterfowl area in the United States (Labedz, 1990). In addition, the wet meadows are the primary source of hay for an industry responsible for a third of the beef cattle production in Nebraska. For both environmental and economic reasons, an understanding of the hydrologic processes associated with Sand Hills wetlands is important. 
Previous studies (Buckwalter, 1983; Rundquist et al., 1987) have examined the utility of Landsat-MSS data for monitoring Sand Hills lakes. Buckwalter (1983), who analyzed photo enlargements of three MSS scenes for each growing season 1973 to 1978 (18 total images) for seven lakes located in two widely spaced study areas, demonstrated that noticeable differences existed in the area-fluctuation patterns between the two test sites. Rundquist et al. (1987), using a total of 58 digital MSS subscenes for 13 lakes in the Crescent Lake and Valentine National Wildlife Refuges (located about $165 \mathrm{~km}$ from one another), examined the relationship between rainfall (timing and amount) and lake-area fluctuations and found that: (1) the patterns for the two locations were statistically different, and (2) lake-surface area at the Crescent site was highly correlated with precipita- tion occurring over the previous 45 days. While both studies provided useful results, they were constrained by the number of available Landsat-MSS images and a minimum of hydrologic data.

The focus for this paper is the "Western Lakes Region" (WLR) of the Sand Hills, which includes southern Sheridan County and northern Garden County (Figure 1). Ground water flow patterns for the region indicate that the WLR coincides with a "saddle" in the regional water table (Figure 2), and that the highest elevations of that surface are slightly north of the boundary between Sheridan and Garden counties. Based on their location in the regional water table, the lakes predominantly in Sheridan County $(n=51)$ are referred to henceforth as the "northern lakes." Those predominantly in Garden County are referred to as the "southern lakes."

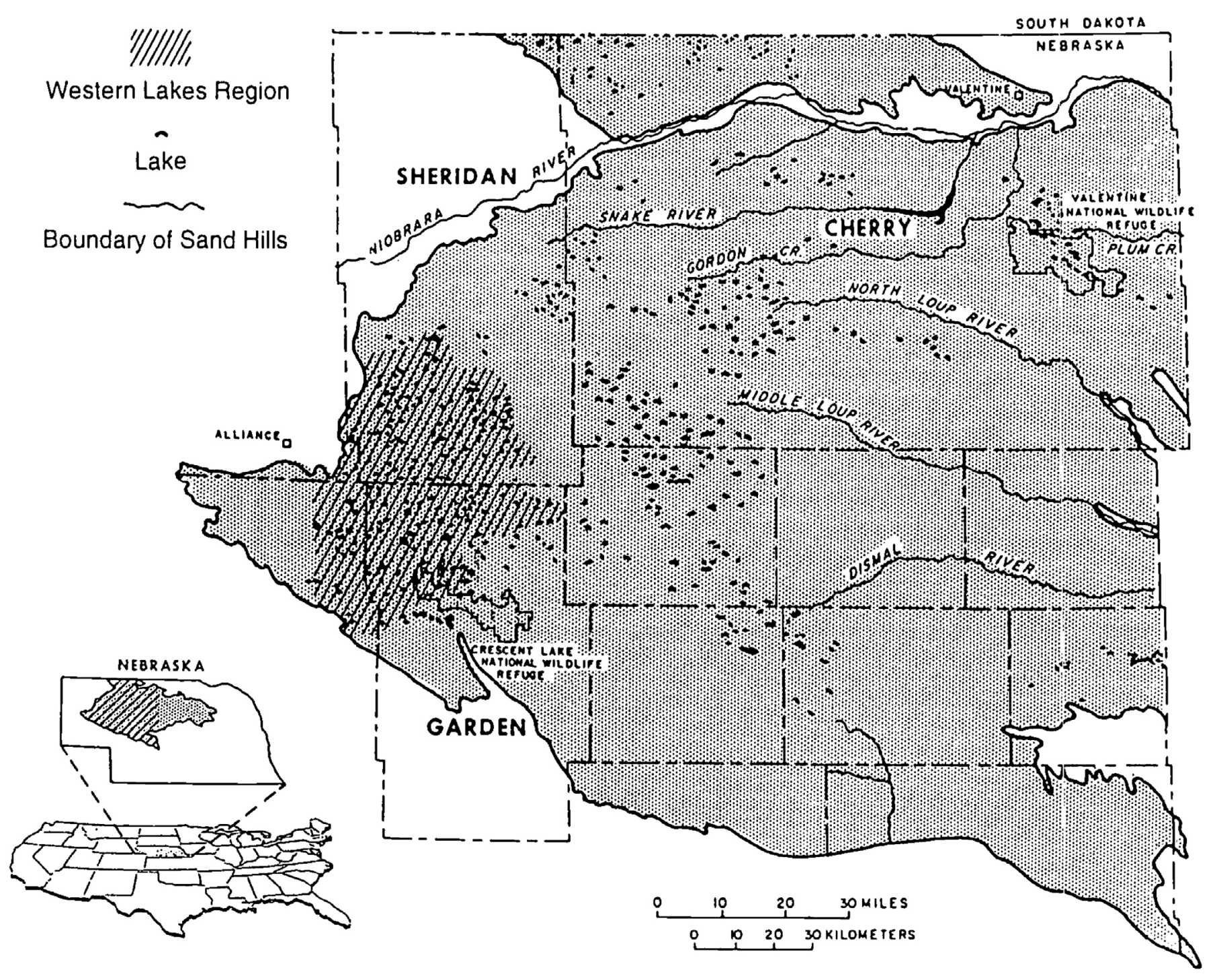

Figure 1. Map Showing Location of Western Sand Hills. The Western Lakes Region occupies the patterned area (modified from Keech and Bentall, 1971). 


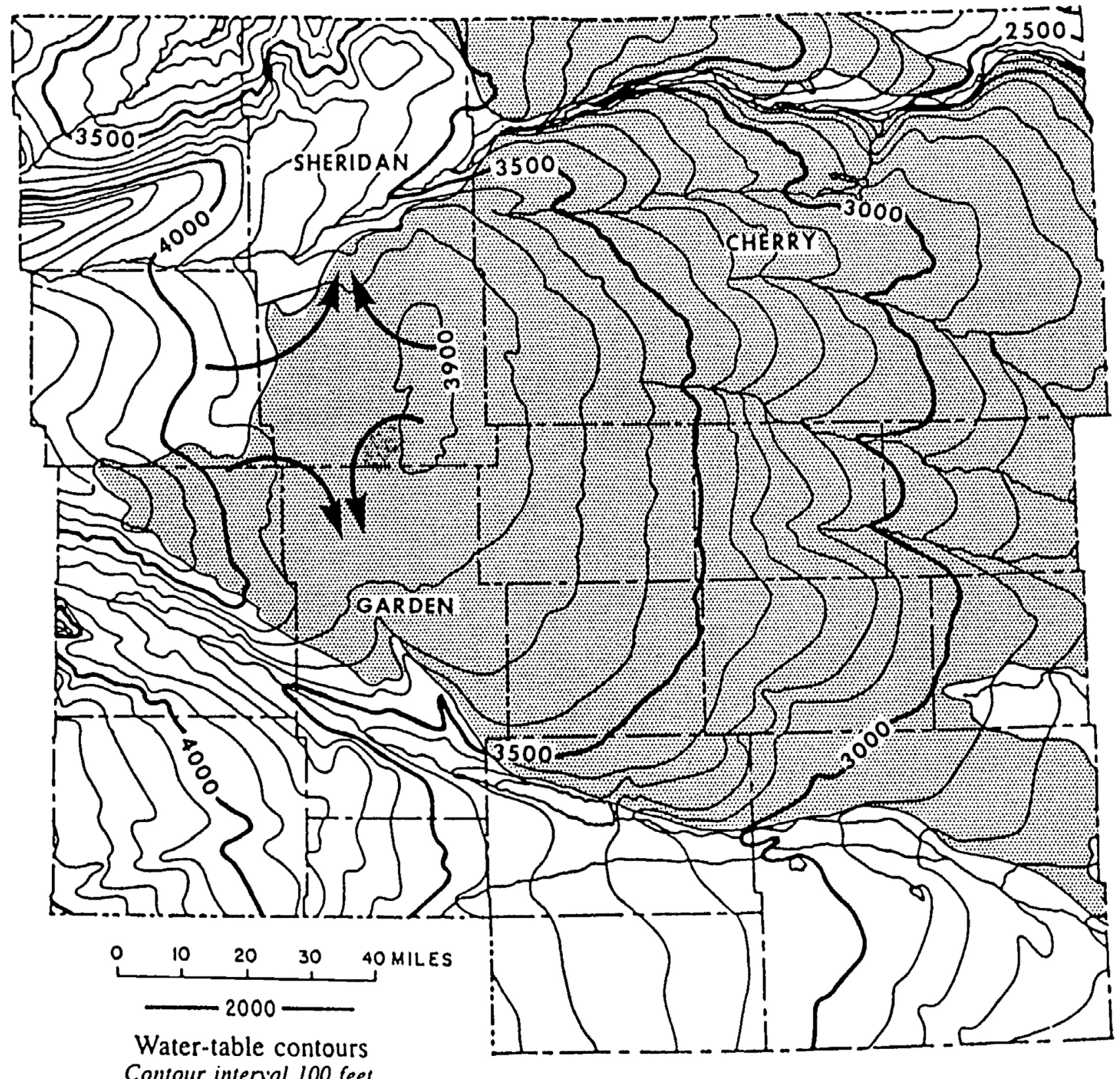
Contour interial 100 feet Datum is mean sea level

Figure 2. Configuration of the Regional Water Table (modified from The Groundwater Atlas of Nebraska, 1986). Arrows pointing north and south indicate the generalized direction of ground water flow, which suggests a "saddle" in the regional flow system.

Sheridan County contains about 521 lakes comprising 16,356 acres, but only 215 are permanent and larger than four acres. Maximum depths tend not to exceed $1.5 \mathrm{~m}$ (McCarraher, 1977). Gosselin et al. (1994), who visited 15 Sheridan County lakes during 1992 and 1993, measured depths between $2.5 \mathrm{~cm}$ to $60 \mathrm{~cm}$, and several were dry between August and October. When the same lakes (and 17 others) were revisited in May, August, and October of 1993, depths ranged from $10 \mathrm{~cm}$ to nearly 2 meters. These results and the presence of (paleo) terraces up to $1.3 \mathrm{~m}$ above the current shorelines indicate that the lakes were once deeper and larger. Thus, it appears that some variability in lake sizes is common in the region.

The 174 lakes in Garden County comprise 13,260 acres and average less than 1 meter in depth. Blue Lake is exceptional at 5 meters deep. Lakes range in size from less than 10 acres to nearly 970 acres (McCarraher, 1977).

Chemical data (McCarraher, 1977; LaBaugh, 1986; Gosselin, 1997; Gosselin et al., 1994, 1997a) indicate that the lakes in the WLR are compositionally diverse, ranging from fresh to brine (total dissolved solids from less than $200 \mathrm{mg} / 1$ to more than 100,000). 
Alkalinity (as $\mathrm{CaCO}_{3}$ ) ranges from less than $200 \mathrm{mg} /$ 1 to more than 100,000 , and $\mathrm{pH}$ is usually greater than 8.0. Ground water, derived primarily from local precipitation, is the principal source of water and dissolved solids for the lakes. Inter-lake chemical differences are a function of local hydrologic variability, which is related to the magnitude of inflow and outflow of water from a lake as well as its age (Gosselin et al., 1994; Gosselin, 1997).

\section{Data and Methods}

A search for all available Landsat MSS images was conducted, but cloud-cover and variations in areal coverage reduced the number of suitable full scenes to 59, with 17 additional subscenes used for analysis of Garden County (Table 1). All were employed to monitor 130 lakes from 1972 to 1989.

Raw Landsat-MSS digital numbers were converted to reflectance using standard procedures (Markham and Barker, 1986). All images were co-registered and resampled to a spatial resolution of 79 meters using a common nearest-neighbor algorithm.

Standing surficial water within each image scene was located by using MSS-4 (0.8 to 1.1 microns) (Work and Gilmer, 1976; White, 1978; Rundquist et al., 1987). This simple procedure is based on the fact that water absorbs virtually all near-infrared energy, and land (especially vegetated) surfaces are highly reflective in the same wavelengths. Therefore, water appears very dark on the MSS-4 images, while land surfaces tend to be light in tone. The challenge is to determine what specific level of MS S-4 reflectivity marks the "threshold" between terrestrial (or aquatic) vegetation and standing surficial water. Thus, the process is one of "level thresholding" of the MSS-4 reflectance data to delineate water bodies.

Thresholds were determined for each MSS-4 scene for the study area, and water bodies were identified. If individual $79 \mathrm{~m}$ picture elements (pixels) were identified as water but were in topographic positions where water could not possibly accumulate, then the threshold for that scene was modified. The final step was to determine the areal extent of surface water for each lake in the study area on a per-image-acquisition basis by means of a simple pixel-counting algorithm.

Lake-elevation data, collected by standard staff-gage procedures, for Roundup, Island, Goose, and Hackberry lakes in the Crescent Lake National Wildlife Refuge (CLNWR) were provided by Dr. Tom Winter, United States Geological Survey. Unfortunately, elevations were not available for other lakes in the study area.
Table 1. Summary of Image Acquisition Dates Used in This Study. Dates having * indicate images available for lakes from the Crescent Lake National Wildlife Refuge only. These lakes include Island, Crescent, Blue, Hackberry, Goose, Roundup, Crane, Christ, Brewer, Gaff, Jones, Gimlet, and Hessey.

\begin{tabular}{|c|c|}
\hline Year & Dates \\
\hline 1972 & August 19; October 12 \\
\hline 1973 & May 15 \\
\hline 1974 & July 4; July 22; September 14; October 20 \\
\hline 1975 & May 14; July 7; August 22 \\
\hline 1976 & May 9; October 9 \\
\hline 1977 & October 13 \\
\hline 1978 & June 13; October 26 \\
\hline 1979 & $\begin{array}{l}\text { June } 25^{*} \text {; August } 1 \text {; September } 6 \text {; September } \\
14^{*} \text {; October } 2^{*}\end{array}$ \\
\hline 1980 & $\begin{array}{l}\text { June } 2^{*} \text {; June } 11^{*} \text {; June } 29^{*} \text {, July } 16^{*} \text {, August } \\
4 \text {; August } 22^{*} \text {; September } 18^{*} \text {; September } \\
27^{*} \text {; October } 14^{*}\end{array}$ \\
\hline 1981 & $\begin{array}{l}\text { April 14*; May 1; May 19; June 6; June 24; } \\
\text { July 11*; July 30; October } 10^{*} \text {; October } 16\end{array}$ \\
\hline 1982 & $\begin{array}{l}\text { April 17*; June 28*; July 16; October } 14^{*} \\
1983 \text { March 1; April 2; May 4; June 21; July } \\
\text { 7; August 8; September 9; September 25; } \\
\text { October } 27\end{array}$ \\
\hline 1984 & $\begin{array}{l}\text { April 12; May 14; May 30; June 15; July 17; } \\
\text { August 10; September 3; September } 19\end{array}$ \\
\hline 1985 & $\begin{array}{l}\text { March 14; April 15; May 1; June 18; July 4; } \\
\text { September 6; October } 24\end{array}$ \\
\hline 1986 & May 4; September 25 \\
\hline 1987 & $\begin{array}{l}\text { May 7; July 10; July 26; August 11; } \\
\text { September 12; September } 28\end{array}$ \\
\hline 1989 & April 18; May 20; July 23 \\
\hline
\end{tabular}

\section{Results And Discussion}

The Utility of Landsat-MSS Data for Investigating the Seasonal and/or Interannual Patterns of Lake-Size Variability

The first objective for our research was to assess the use of Landsat-MSS data for examining seasonal and/ or interannual patterns of lake-area fluctuation. To address this objective, one must consider the fact that most of the interdunal valleys in the region are broad and flat. Therefore, one would expect a close correspondence be- 
tween surface-area and lake-elevation measurements. Basically, lake areas should increase as lake elevations increase, and vice-versa. We investigated the lake area changes over time for Crane, Island, Hackberry, and Roundup lakes in the CLNWR, based on 59 full or partial satellite scenes from 1979 to 1987 (Figure 3). We compared these areal fluctuations to in-situ ground water and surface water measurements at CLNWR (Winter, 1986, and unpublished data; Keen, 1992; Khisty, 1997). These are the only lakes that have staff gage measurements in the Western Lakes region and they have only been measured since 1982.

Figure 4 compares lake area and lake elevation measurements for one selected water body. The lake elevation hydrograph for Island Lake shows the characteristic increase in water levels from mid-September into early or late spring, followed by a progressive decrease from late spring until the first killing frost (Gosselin et al., 1997b; Drda, 1998). In general, the lake area hydrographs have a pattern that is similar to the lake elevations, and the peak in lake area occurs within the same time frame that the lake elevation is within 0.20 feet of its maximum. In addition, the minimum elevations and areas generally coincide and occur in mid-to-late September. Combining the lake area measurements for 1982 to 1989 (Figure 3 ), for which we have ground-truth data (lake elevation), with those from 1972 to 1982 indicates that the seasonal and interannual variability has been fairly regular over the period of record with the exception of one data point for Island Lake in 1978. In this case, the lake was artificially lowered to modify the fish populations.

Although there is a general coincidence of lake area and elevation, a comparison of 39 area and elevation measurements obtained within about 10 days of each other for Island, Crane, Hackberry, and Roundup lakes indicate that these two parameters are at best only weakly correlated when all data are considered (Table 2 and Figure 5). If we consider seasonal fluctuations, within which there are times when the amount of water in a lake is generally increasing (gaining) and corresponding periods when the amount is decreasing (losing), we find that the correlations are highly variable from 0.99 to -0.16 (Table 2 ). This apparent variability in correlation between the elevation and area is the result of several factors. First, lake elevation data are inherently more accurate than the $79 \mathrm{~m}$ spatial resolution of the satellite data as used for

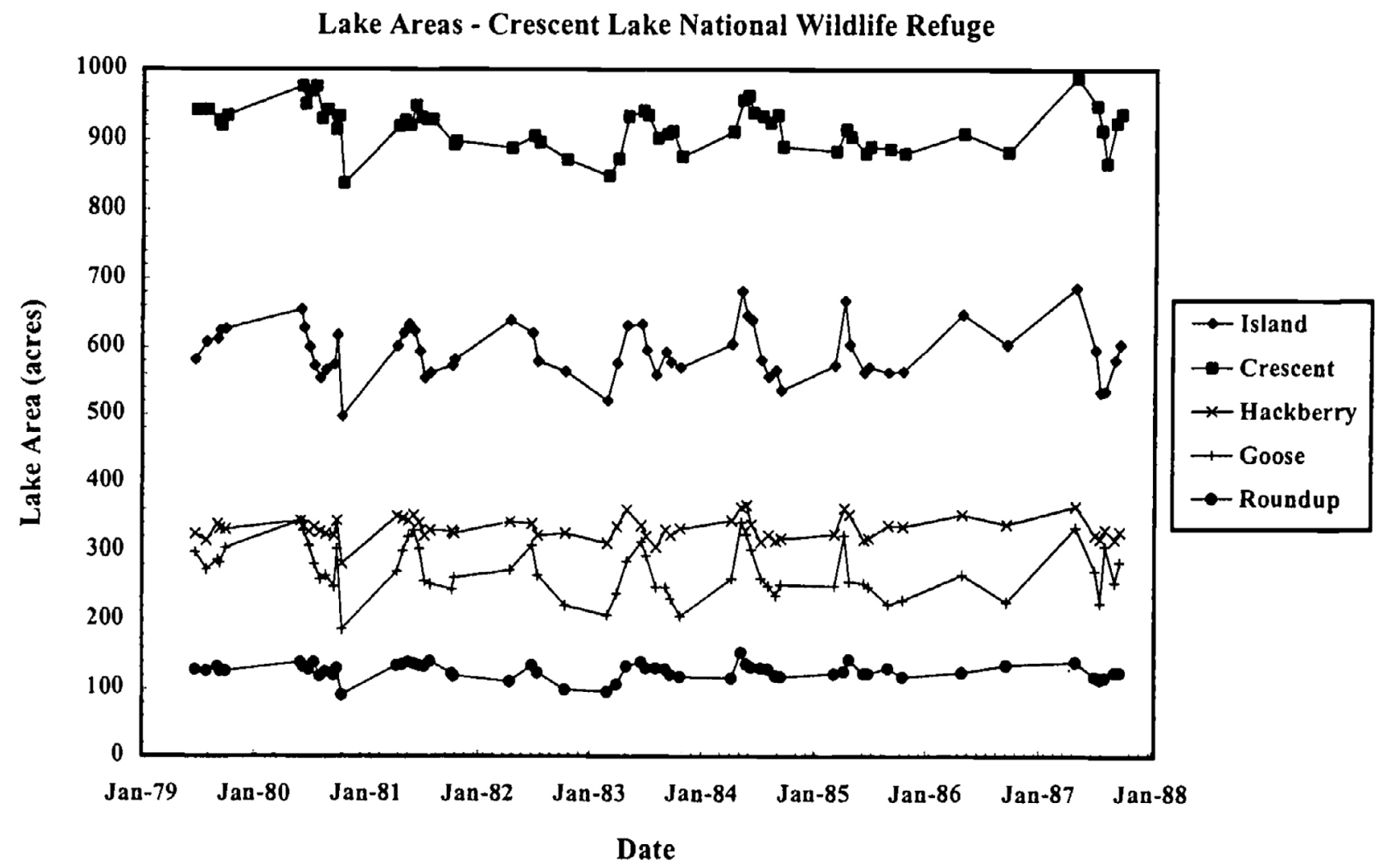

Figure 3. Lake Area Hydrographs for Island, Crescent, Hackberry, Goose, and Roundup Lakes in the Crescent Lake National Wildlife Refuge. 


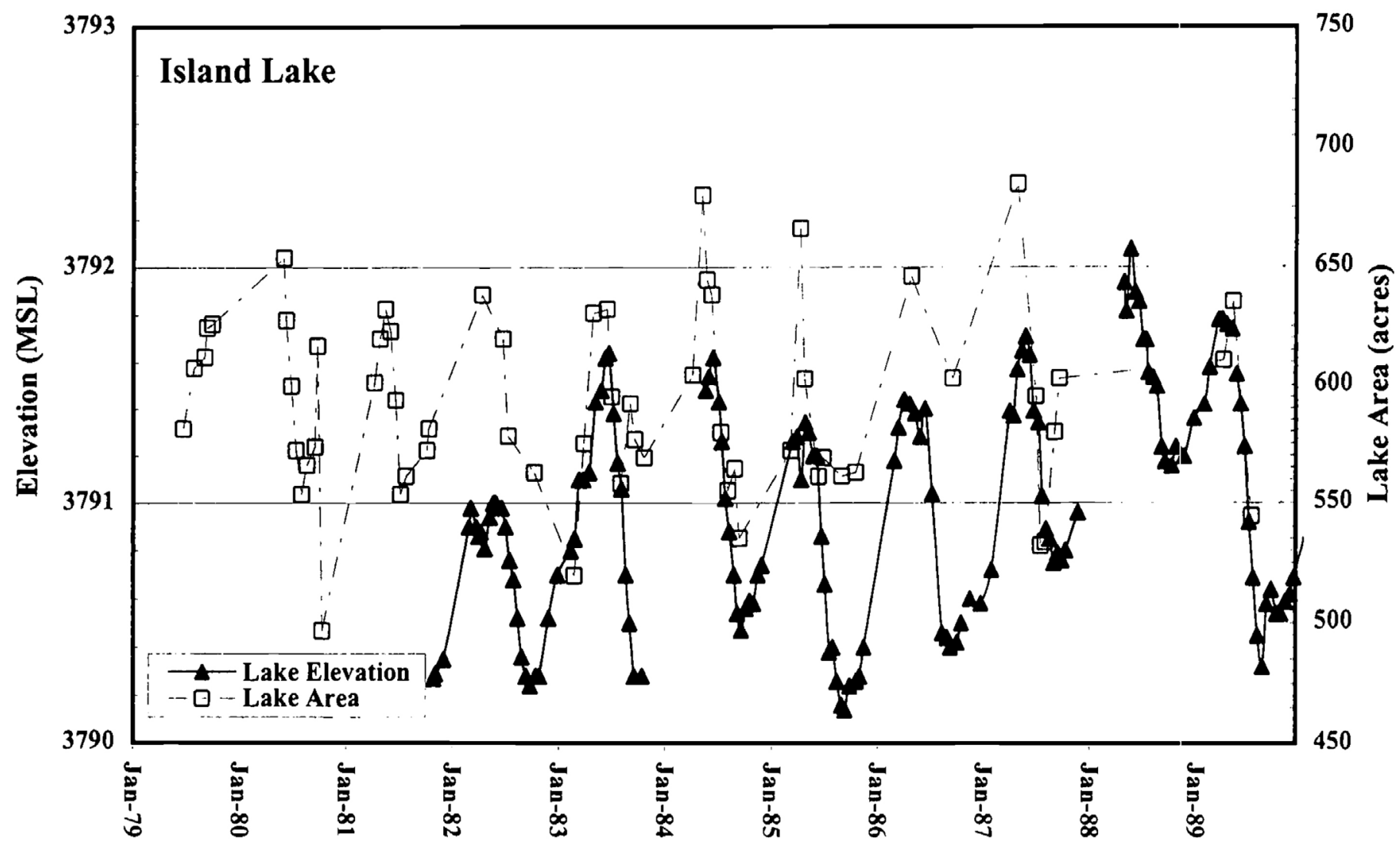

Figure 4. Comparison of Lake Area and Elevation Measurements for Island Lake from 1979 to 1989.

Table 2. Lake Elevation and Lake Area Correlation Coefficients for Island, Crane, Hackberry, and Roundup Lakes in the Crescent Lake National Wildlife Refuge. Gaining periods represent the time that the amount of water in the lake is generally increasing. This period usually is from late September to mid-June. Declining period represents the time when the amount of water in the lake is generally decreasing. All data includes 39 images and water level measurements.

\begin{tabular}{|c|c|c|c|c|c|c|c|c|}
\hline \multirow[t]{2}{*}{$\begin{array}{l}\text { Lake Level } \\
\text { Change }\end{array}$} & \multirow{2}{*}{$\frac{\text { All Data }}{1981-1989}$} & \multicolumn{2}{|c|}{$\begin{array}{l}\text { Island } \\
\text { Lake }\end{array}$} & \multicolumn{2}{|l|}{$\begin{array}{l}\text { Crane } \\
\text { Lake }\end{array}$} & \multicolumn{2}{|c|}{$\begin{array}{l}\text { Hackberry } \\
\text { Lake }\end{array}$} & \multirow{2}{*}{$\begin{array}{c}\begin{array}{c}\text { Roundup } \\
\text { Lake }\end{array} \\
0.35\end{array}$} \\
\hline & & 0.58 & & 0.71 & & 0.39 & & \\
\hline Gaining & $9 / 25 / 83$ to $6 / 15 / 84$ & 0.99 & $10 / 27 / 83$ to $6 / 15 / 84$ & 0.95 & $9 / 25 / 83$ to $6 / 15 / 84$ & 0.75 & & \\
\hline Declining & & & & & & & $6 / 15 / 84$ to $9 / 19 / 84$ & 0.91 \\
\hline
\end{tabular}

lake area. With this coarse image resolution, it seems unreasonable to expect subtle changes in lake elevation to be detected in the lake area measurements. In fact, an important finding is that lake area usually begins to decrease earlier than lake elevation (Figure 4). The explanation for this finding is related to a second, even more important, factor. That is, during the time when the lake elevation is reaching its peak, the density of lake-margin vegetation is also increasing. Because of this increase in cover, the water beneath the canopy cannot be detected by the Landsat-MSS.

Nevertheless, even with these limitations, the MSS data record seasonal and interannual variations in lake area. Our analysis revealed a trend of increasing surface 


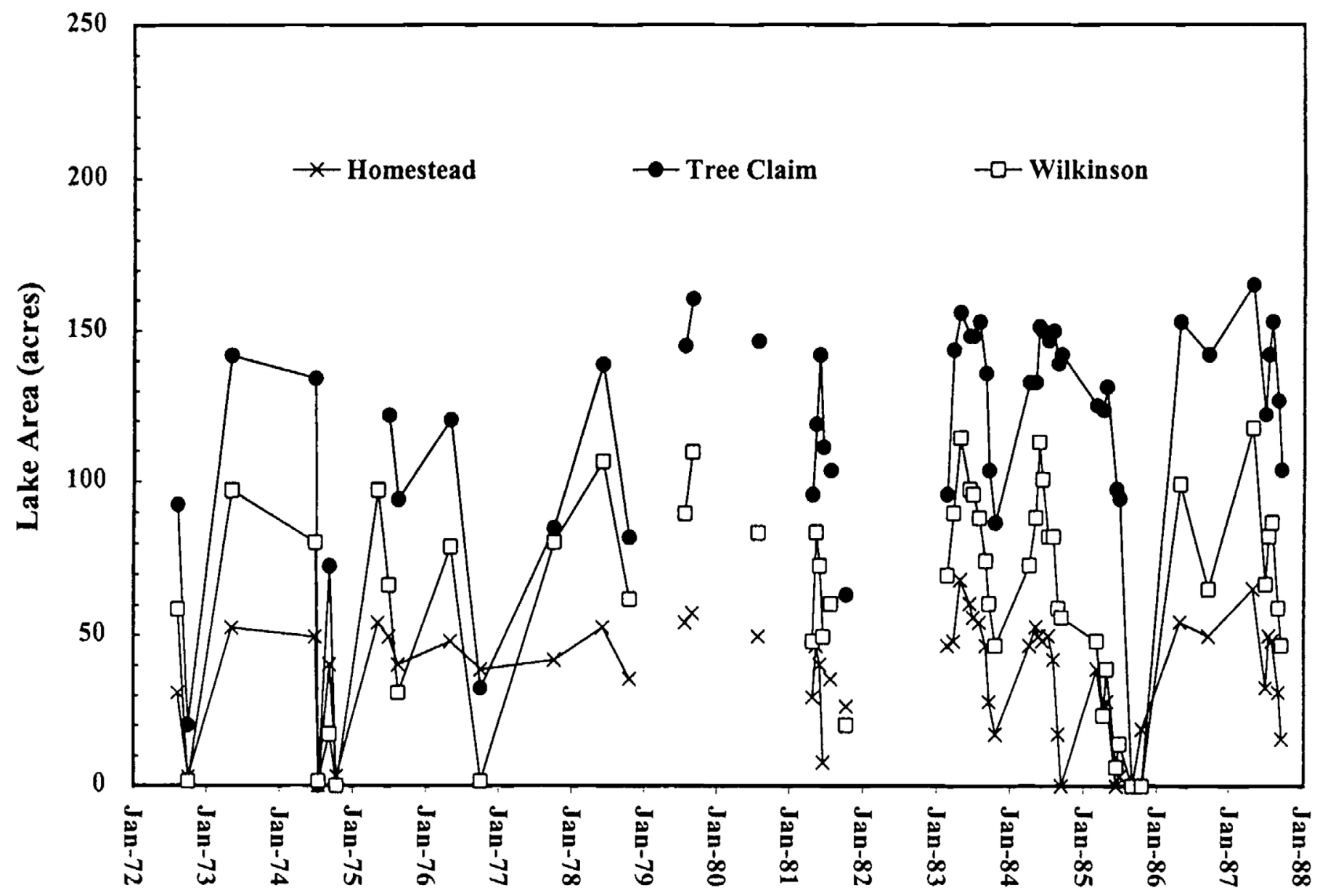

Figure 5. Lake Area vs. Lake Elevation for Island, Hackberry, Crane, and Roundup Lakes in the Crescent Lake National Wildlife Refuge. Values on the graph are correlation coefficients (see Table 2 for additional information).

area from mid-to-late September of a given year with maximum spatial extent occurring between late April and mid-June of the following year. The areal maximum was followed by a general decrease in lake size until the cycle began again.

The Utility of Measured Lake-Area Fluctuations for Elucidating the Hydrologic Characteristics of GroundwaterDominated Lakes

Our second objective was focused on determining whether or not the fluctuations in lake areas, as measured by means of Landsat-MSS data, are useful for elucidating the hydrologic characteristics of groundwater-dominated lakes. Landsat-MSS data provide an historical record back to 1972 , so one can monitor lakes for which no site-specific staff-gage data have been collected. For the period and particular image-acquisition dates defined by the availability of suitable Landsat-MSS datasets (19721989), the 130 lakes examined in this study ranged in size from $<1.5$ acres to $>910$ acres, with a mean of $105 \pm 22$ acres and a 95 percent confidence interval (Table 2). A histogram of lake-area sizes (Figure 6) indicate that they are generally larger than 25 acres but less than 200 acres. The northern lakes, mainly in Sheridan County $(n=51)$, averaged $80 \pm 17$ acres in size. These southern lakes in Garden County $(n=79)$ averaged $122 \pm 34$ acres, which was statistically different $(p<0.5)$ than the average area for the northern lakes. Despite the relatively coarse resolution of Landsat-MSS data and the use of a simple levelthreshold procedure, the data appear to be useful for monitoring and measuring lake areas over long periods of time. 


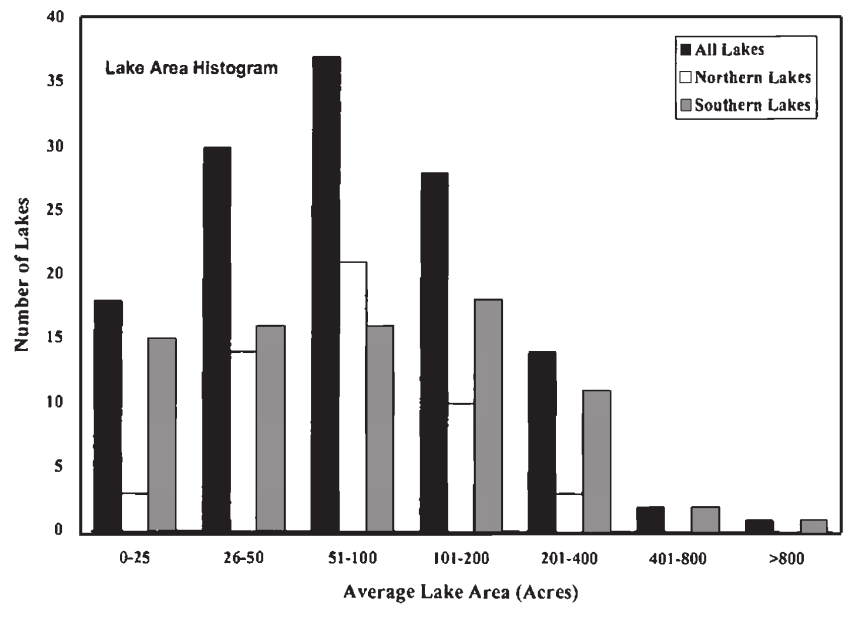

Figure 6. Histogram of Average Area for the 130 Lakes Examined in This Study. Histograms are also presented for the northern and southern lakes (date given in Table 1).

In addition to providing information about lake size, the measurements derived from analyses of LandsatMSS data allow for meaningful inferences about the hydrologic variations of individual, relatively small lakes. This type of information is particularly useful because the hydrologic variations control, to varying degrees, the chemical and biological characteristics of individual lakes. To examine relative variability in size over geographic space, we calculated a coefficient of variation (CV) for each of the 130 lakes (Table 3), where CV = Standard Deviation/Lake Area Mean.

A cursory evaluation for the northern lakes indicates that the seasonal patterns in lake areas are similar to the southern lakes; however, several northern lakes, such as Homestead, Tree Claim, and Wilkinson, dried up at least five times during the period of record (Figure 5). Field observations confirm their ephemeral characteristics.

A comparison of the CVs for the southern versus northern lakes using an F-test $(p=0.05)$ indicated that there is a statistically significant difference in lake-size variability between the two regions. Thirty four percent of the lakes in the southern region have CVs less than 0.20 compared to 16 percent in the north. One possible explanation for the differences in variability may be that the southern and northern lakes are in different parts of the regional ground water flow system. The groundwater-fed lakes in the lower part of the southward flowing regional ground water system might be expected to be relatively more stable as recorded in the CVs of 0.06 , 0.07, 0.10, and 0.11 for Hackberry, Island, Crane, and Roundup lakes, respectively. On the other hand, lakes in the upper (northern) parts of the ground water flow system would be expected to be more variable. However, the CVs in Table 1 indicate that there is substantial local hydrologic complexity throughout the WLR and the generalization about lakes in the lower and upper part of the ground water flow is too simplistic.

Evidence for complexity is consistent with previous interpretations related to lake chemistry (Gosselin et al., 1994; Gosselin, 1997) that local differences in hydrology between lakes regulates the extent to which geochemical processes will proceed. Our current understanding of the factors that contribute to the development of local hydrologic regimes is limited. One factor that could influence the local regime is the distribution and thickness of geologic materials, which directly affects aquifer properties such as hydraulic conductivity and the extent to which the ground water and surface water interact. In the WLR, crescent-shaped barchan dunes are prevalent (Swinehart, 1990). They vary from closely spaced to widely spaced, have variable heights, and have interdunal valleys that occupy variable amounts of area ranging from 20 to 40 percent. Recent work in the central Sand Hills on the hydrology of interdunal valleys suggests that the topographic relationships between the interdunal areas and the adjacent dunes strongly influence the hydrologic characteristics of individual valleys and by inference the lakes that may occupy them (Gosselin et al., 1999).

Six lakes in the study area (unnamed B, Eldred, Mellis, unnamed $\mathrm{AD}$, Adams, and unnamed $\mathrm{AA}$ ) had a $\mathrm{CV}$ exceeding 0.80 , which indicates substantially greater variation than other lakes in the region. An examination of topographic maps and aerial photographs documented that these valleys are used for hay production and that their hydrology had been modified by either ditching or the pumping of water for irrigation. These data indicate that MSS data has the potential to be used to monitor land-use changes in these wetland and lake environments as well as documenting natural hydrologic variations.

\section{Acknowledgments}

The research was supported by the U.S. Department of Energy (DOE) National Institute for Global Environmental Change (NIGEC) through the NIGEC Great Plains Regional Center at the University of NebraskaLincoln (DOE Cooperative Agreement No. DE-FCO390ER61010). Financial support does not constitute an endorsement by DOE of the views expressed in this article/report. We also acknowledge support provided by the Conservation and Survey Division and the Nebraska Space Grant Consortium. 


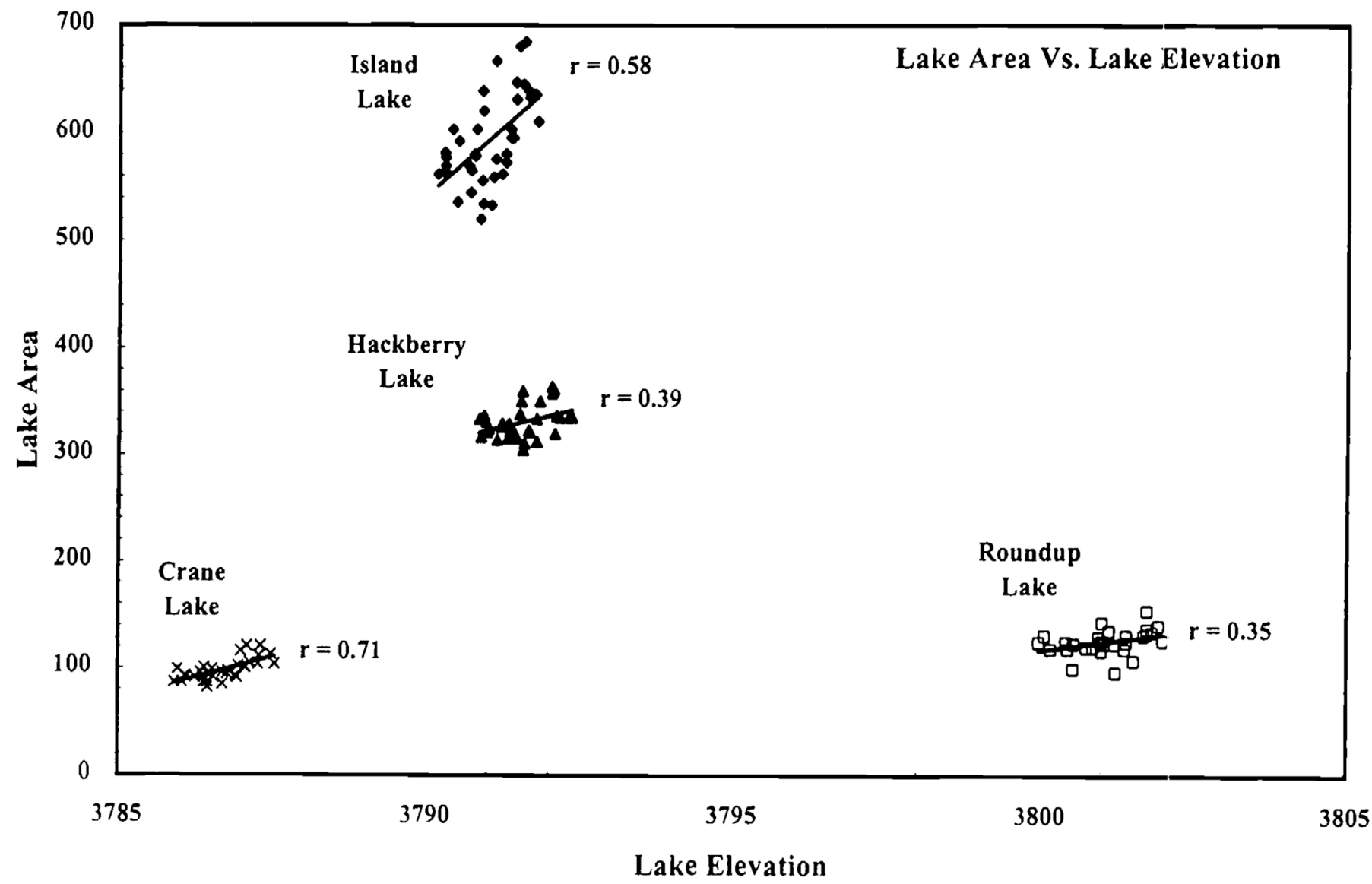

Figure 7. Lake Area Hydrographs for Northern Lakes. Data is from 1972 to 1987 for Homestead, Tree Claim, and Wilkinson Lakes.

\section{Literature Cited}

Bobba, A., R. Bukata, and J. Jerome, 1992. Digitally Processed Satellite Data as a Tool in Detecting Potential Groundwater Flow Systems. Journal of Hydrology 131:25-62.

Buckwalter, D., 1983. Monitoring Nebraska's Sandhills Lakes. Resource Report No. 10, Conservation and Survey Division, University of Nebraska-Lincoln, Lincoln Nebraska, 42 pp.

Drda, S., 1998. Hydrology of Two Interdunal Valleys in the Nebraska Sand Hills, M.S. Thesis, Geosciences Department, University of Nebraska-Lincoln, Lincoln Nebraska, 88 pp.

Gilmer, D., E. Work, Jr., J. Colwell, and D. Rebel, 1980. Enumeration of Prairie Wetlands With Landsat and Aircraft Data. Photogrammetric Engineering and Remote Sensing 46 (5):631-634.

Gitelson, A., G. Garbuzov, F. Szilagyi, K. Mittenzwey, A. Karnieli, and A. Kaiser, 1993. Quantitative Remote Sensing Methods for Real-Time Monitoring of Inland Waters Quality. International Journal of Remote Sensing 14(7):1269-1295.

Gosselin, D. C., 1997. Major-Ion Chemistry of Compositionally Diverse Lakes, Western Nebraska, U.S.A.: Implications for Paleoclimatic Interpretations. Journal of Paleolimnology 17:33-49.
Gosselin, D. C., S. Drda, F. E Harvey, and J. Goeke, 1999. Hydrologic Setting of Two Interdunal Valleys in the Central Sand Hills of Nebraska. Journal of Groundwater (in review).

Gosselin, D. C., M. Khisty, D. C. Rundquist, and F. E. Harvey, 1997a. Natural Responses of Shallow Lakes and Wetlands to Climatic/Environmental Change: Focus on the Nebraska Sand Hills. In: Proceedings of The Great Plains Symposium 1997: The Ogallala Aquifer, "Managing for Drought and Climate Change," pp. 52-71.

Gosselin, D. C., P. E. Nabelek, Z. E. Peterman, and S. Sibray, 1997b. Oxygen, Hydrogen, and Strontium Isotopes in Saline Alkaline Lakes From Western Nebraska, U.S.A. Journal of Paleolimnology 17:51-65.

Gosselin, D. C., S. Sibray, and J. Ayers, 1994. Geochemistry of Closed-Basin, K-Rich Alkaline Lakes, Western Sand Hills, Nebraska. Geochimica et Cosmochimica Acta 58: 1403-1418.

Groundwater Atlas of Nebraska, 1986. Resource Atlas 4, Conservation and Survey Division, University of Nebraska-Lincoln, Lincoln Nebraska.

Keech, C. F. and R. Bentall, 1971. Dunes on the Plains. Resource Report 4, Conservation and Survey Division, University of Nebraska-Lincoln, Lincoln Nebraska.

Keen, K L., 1992. Geomorphology, Recharge, and Water-Ta- 
ble Fluctuations in Stabilized Sand Dunes: The Nebraska Sand Hills, U.S.A. Ph.D. Dissertation, University of Minnesota, 500 pp.

Khisty, M. J., 1997. Simulating the Shift in Position of Hinge Lines Between Two Shallow, Flow-Through Lakes. M.S. Thesis, Geosciences Department, University of NebraskaLincoln, Lincoln, Nebraska, 34 pp.

LaBaugh, J. W., 1986. Limnological Characteristics of Selected Lakes in the Nebraska Sandhills, U.S.A., and Their Relation to Chemical Characteristics of Adjacent Groundwater. Journal of Hydrology 86:279-298.

Labedz, T. E., 1990. Birds. In: Atlas of the Sand Hills, A. Bleed and C. F. Flowerday (Editors). Resource Atlas 5a, Conservation and Survey Division, University of Nebraska-Lincoln.

Markham, B. and J. Barker, 1986. Landsat MSS and TM PostCalibration Dynamic Ranges, Exoatmospheric Reflectances and At-Satellite Temperatures. EOSAT: Landsat Technical Notes, No. 1, August.

McCarraher, D. B., 1977. Nebraska Sandhill Lakes. Nebraska Game and Parks Commission. Lincoln, Nebraska.

Rundquist, D. C., 1983. Wetland Inventories of Nebraska's Sandhills. Resource Report 9, Conservation and Survey Division, University of Nebraska-Lincoln, Lincoln Nebraska, 46 pp.
Rundquist, D., M. Lawson, L. Queen, and R. Cerveny, 1987. The Relationship Between Summer-Season Rainfall and Lake-Surface Area. Water Resources Bulletin 23(3):493-508.

Swinehart, J. B., 1990, Wind-Blown Deposits. In: Atlas of the Sand Hills, A. Bleed and C. Flowerday (Editors). Conservation and Survey Division, University of Nebraska-Lincoln, Resource Atlas No. 5a, Lincoln, Nebraska, pp. 43-56.

White, M. E., 1978, Reservoir Surface Area From Landsat Imagery. Photogrammetric Engineering and Remote Sensing 44:1421-1426.

Winter, T. C., 1986, Effect of Ground-Water Recharge on Configuration of the Water Table Beneath Sand Dunes and on Seepage in Lakes in the Sandhills of Nebraska, U.S.A. Journal of Hydrology 86:221-237.

Work, E. and D. Gilmer, 1976. Utilization of Satellite Data for Inventorying Prairie Ponds and Lakes. Photogrammetric Engineering and Remote Sensing 42(5):685-694.

Yacobi, Y., A. Gitelson, and M. Mayo, 1995. Remote Sensing of Chlorophyll in Lake Kinneret Using High-Spectral-Resolution Radiometer and Landsat TM: Spectral Features of Reflectance and Algorithm Development. Journal of Plankton Research 17(11):2155-2173. 
Table 3. Data (in acres) Estimated From 59 LANDSAT MSS Images for 130 Lakes From The Western Lakes Region, Sand Hills, Nebraska. For Dillings, School Island, and Tree Claim, data from May 14, 1975, were eliminated because the lakes were not on the image. One data point in 1978 was eliminated from Island lake because the lake was drained to manage game fish population.

\begin{tabular}{|c|c|c|c|c|c|c|}
\hline \multirow[b]{2}{*}{ Lake } & \multicolumn{2}{|c|}{ UTM Coordinates } & \multirow{2}{*}{$\begin{array}{c}\text { Maximum } \\
\text { Area }\end{array}$} & \multirow{2}{*}{$\begin{array}{l}\text { Minimum } \\
\text { Area }\end{array}$} & \multirow{2}{*}{$\begin{array}{c}\text { Average } \\
\text { Area }\end{array}$} & \multirow{2}{*}{$\begin{array}{l}\text { Coefficient } \\
\text { of Variation }\end{array}$} \\
\hline & Easting & Northing & & & & \\
\hline \multicolumn{7}{|c|}{ Garden County } \\
\hline Crescent & 715511 & 4620231 & 989 & 791 & 913 & 0.0426 \\
\hline Twin Lakes & 704838 & 4620315 & 227 & 29 & 82 & 0.5059 \\
\hline Blue & 713315 & 4620893 & 321 & 256 & 279 & 0.0473 \\
\hline Swan & 708290 & 4621585 & 464 & 281 & 382 & 0.0766 \\
\hline Jones & 711290 & 4622047 & 37 & $<1.5$ & 16 & 0.3977 \\
\hline Crane & 718553 & 4622728 & 120 & 80 & 99 & 0.1014 \\
\hline Hackberry & 713092 & 4623410 & 364 & 275 & 327 & 0.0557 \\
\hline Christ & 719901 & 4623982 & 23 & $<1.5$ & 15 & 0.3086 \\
\hline Island & 716626 & 4623998 & 685 & 520 & 603 & 0.0681 \\
\hline Lower Harrison & 706957 & 4624483 & 102 & 29 & 50 & 0.3174 \\
\hline Deer & 723745 & 4624621 & 143 & 54 & 108 & 0.1957 \\
\hline “F” & 713798 & 4625101 & 68 & $<1.5$ & 18 & 0.5530 \\
\hline Charleys & 705595 & 4625207 & 42 & 26 & 33 & 0.0951 \\
\hline Roundup & 715272 & 4625273 & 153 & 62 & 124 & 0.1089 \\
\hline Upper Harrison & 706912 & 4625336 & 77 & 8 & 22 & 0.4625 \\
\hline "A" & 699815 & 4625839 & 102 & 11 & 70 & 0.2661 \\
\hline “B” & 704088 & 4626314 & 39 & $<1.5$ & 29 & 0.2055 \\
\hline “D” & 695931 & 4626319 & 71 & $<1.5$ & 16 & 1.3871 \\
\hline Black Steer & 722712 & 4626508 & 242 & 139 & 196 & 0.1219 \\
\hline Gimlet & 713700 & 4626565 & 83 & 17 & 55 & 0.2210 \\
\hline Bean & 704815 & 4627278 & 353 & 177 & 280 & 0.1626 \\
\hline Gaff & 715974 & 4627671 & 76 & 17 & 51 & 0.2065 \\
\hline Brewer & 719249 & 4627866 & 56 & 20 & 39 & 0.2167 \\
\hline Goose & 712222 & 4628414 & 339 & 205 & 262 & 0.1293 \\
\hline Sand & 693731 & 4628982 & 173 & 88 & 133 & 0.1127 \\
\hline “C” & 700151 & 4629038 & 51 & $<1.5$ & 22 & 0.6462 \\
\hline Smith & 705845 & 4629249 & 210 & 65 & 107 & 0.2701 \\
\hline Rush & 709644 & 4629578 & 66 & 19 & 39 & 0.3322 \\
\hline Campbell & 713566 & 4629688 & 31 & $<1.5$ & 18 & 0.3606 \\
\hline “E” & 722909 & 4629928 & 37 & 5 & 24 & 0.2676 \\
\hline Hessey & 719379 & 4630082 & 171 & 42 & 106 & 0.2675 \\
\hline Moffit & 695003 & 4631222 & 160 & 68 & 108 & 0.1579 \\
\hline Wolf & 719941 & 4631322 & 299 & 173 & 218 & 0.1150 \\
\hline Gullet & 715098 & 4631791 & 48 & 8 & 20 & 0.4316 \\
\hline Martin & 705537 & 4631972 & 48 & $<1.5$ & 16 & 0.7541 \\
\hline Eldred & 702243 & 4632264 & 22 & $<1.5$ & 0 & 6.0123 \\
\hline Alkalai & 699561 & 4632412 & 230 & $<1.5$ & 146 & 0.3518 \\
\hline “G” & 712694 & 4632807 & 65 & 2 & 35 & 0.3872 \\
\hline “ $\mathrm{H}$ ” & 719167 & 4633225 & 42 & 3 & 18 & 0.4715 \\
\hline Heskett & 714496 & 4633252 & 85 & 34 & 50 & 0.1991 \\
\hline Maverick & 716859 & 4633271 & 214 & 91 & 131 & 0.2093 \\
\hline Reno & 709724 & 4633489 & 139 & 17 & 27 & 0.1456 \\
\hline Whitehead & 707264 & 4633756 & 273 & 147 & 194 & 0.1442 \\
\hline Ashburger & 712067 & 4634654 & 473 & 126 & 381 & 0.2157 \\
\hline Sage & 709615 & 4635156 & 51 & 23 & 37 & 0.1957 \\
\hline Ramsay Lakes & 711018 & 4636153 & 120 & 31 & 84 & 0.1873 \\
\hline “I” & 704660 & 4637020 & 96 & 35 & 51 & 0.2131 \\
\hline Breman & 709532 & 4637531 & 134 & 79 & 107 & 0.1254 \\
\hline
\end{tabular}


Table 3 (continued). Data (in acres) Estimated From 59 LANDSAT MSS Images for 130 Lakes From The Western Lakes Region, Sand Hills, Nebraska. For Dillings, School Island, and Tree Claim, data from May 14, 1975, were eliminated because the lakes were not on the image. One data point in 1978 was eliminated from Island lake because the lake was drained to manage game fish population.

\begin{tabular}{|c|c|c|c|c|c|c|}
\hline \multirow[b]{2}{*}{ Lake } & \multicolumn{2}{|c|}{ UTM Coordinates } & \multirow{2}{*}{$\begin{array}{l}\text { Maximum } \\
\text { Area }\end{array}$} & \multirow{2}{*}{$\begin{array}{l}\text { Minimum } \\
\text { Area }\end{array}$} & \multirow{2}{*}{$\begin{array}{c}\text { Average } \\
\text { Area }\end{array}$} & \multirow{2}{*}{$\begin{array}{l}\text { Coefficient } \\
\text { of Variation }\end{array}$} \\
\hline & Easting & Northing & & & & \\
\hline \multicolumn{7}{|c|}{ Garden County (cont'd.) } \\
\hline Mellis & 711897 & 4638131 & 116 & $<1.5$ & 24 & 1.3551 \\
\hline “AD” & 701890 & 4638384 & 150 & 8 & 46 & 0.7970 \\
\hline Sandbeach & 712589 & 4640451 & 404 & 207 & 286 & 0.1512 \\
\hline Jordan & 703502 & 4640671 & 105 & 22 & 73 & 0.2090 \\
\hline "J" & 707983 & 4640972 & 72 & 2 & 47 & 0.3323 \\
\hline Merrill & 705828 & 4641191 & 276 & 130 & 210 & 0.1483 \\
\hline Clough & 701844 & 4642984 & 159 & 51 & 114 & 0.1838 \\
\hline Bluebaker & 713846 & 4643489 & 211 & $<1.5$ & 131 & 0.3378 \\
\hline Whitehead 2 & 706800 & 4643726 & 168 & 63 & 126 & 0.1828 \\
\hline “L” & 710164 & 4644202 & 69 & $<1.5$ & 46 & 0.3589 \\
\hline Mohall & 717676 & 4644213 & 43 & 2 & 25 & 0.3204 \\
\hline Marys & 711724 & 4644364 & 131 & 28 & 77 & 0.3218 \\
\hline Murphy & 713829 & 4645049 & 86 & $<1.5$ & 28 & 0.6803 \\
\hline "K" & 716488 & 4645892 & 76 & $<1.5$ & 39 & 0.4648 \\
\hline Beck & 702640 & 4646072 & 310 & 177 & 235 & 0.1335 \\
\hline Ross & 721606 & 4646227 & 57 & $<1.5$ & 33 & 0.4058 \\
\hline Belle & 711893 & 4647502 & 290 & 66 & 181 & 0.3026 \\
\hline Hills & 702122 & 4648879 & 262 & 117 & 194 & 0.1700 \\
\hline Adams & 720387 & 4649153 & 35 & $<1.5$ & 10 & 1.1061 \\
\hline Schoonover & 709870 & 4650337 & 697 & 481 & 625 & 0.0801 \\
\hline Stockholm S & 716109 & 4650987 & 88 & $<1.5$ & 39 & 0.6866 \\
\hline Roland & 713701 & 4651180 & 93 & 2 & 61 & 0.3404 \\
\hline Herman & 711233 & 4651425 & 140 & 2 & 84 & 0.4286 \\
\hline Stockholm N & 715072 & 4651552 & 182 & 96 & 152 & 0.1076 \\
\hline Dennis & 721719 & 4652657 & 37 & $<1.5$ & 15 & 0.7169 \\
\hline “M" & 716834 & 4653203 & 140 & $<1.5$ & 70 & 0.4265 \\
\hline “N” & 702340 & 4653564 & 46 & $<1.5$ & 27 & 0.4544 \\
\hline \multicolumn{7}{|c|}{ Sheridan County } \\
\hline Nelson & 706161 & 4653989 & 88 & $<1.5$ & 50 & 0.4288 \\
\hline Patterson N & 716221 & 4654200 & 71 & 22 & 51 & 0.2436 \\
\hline Strong & 708907 & 4654726 & 187 & 28 & 100 & 0.3737 \\
\hline Floyd & 712742 & 4654970 & 369 & 222 & 288 & 0.1035 \\
\hline Hiers & 701698 & 4656201 & 114 & 35 & 82 & 0.1842 \\
\hline McFall & 709059 & 4656208 & 60 & 9 & 44 & 0.1990 \\
\hline McFall 2 & 704966 & 4656527 & 116 & 23 & 78 & 0.2404 \\
\hline Ashburger 2 & 708232 & 4658599 & 80 & 6 & 45 & 0.4008 \\
\hline Hancock & 711579 & 4659104 & 79 & $<1.5$ & 40 & 0.4378 \\
\hline Lane & 704502 & 4659269 & 72 & 22 & 53 & 0.2120 \\
\hline Harris & 716056 & 4659736 & 82 & 9 & 60 & 0.2319 \\
\hline “O” & 704917 & 4660230 & 51 & $<1.5$ & 28 & 0.6387 \\
\hline Potash & 700348 & 4660368 & 66 & 19 & 51 & 0.1759 \\
\hline Thompson & 713275 & 4661932 & 185 & 134 & 164 & 0.0705 \\
\hline Palmer & 698874 & 4662215 & 190 & 17 & 108 & 0.3225 \\
\hline Welsh & 716234 & 4663005 & 91 & 28 & 55 & 0.2166 \\
\hline Lily & 700723 & 4663308 & 86 & $<1.5$ & 47 & 0.4419 \\
\hline Mulhull & 708472 & 4663528 & 106 & $<1.5$ & 60 & 0.4622 \\
\hline Bower & 699748 & 4663709 & 153 & 51 & 102 & 0.2143 \\
\hline
\end{tabular}


Table 3 (continued). Data (in acres) Estimated From 59 LANDSAT MSS Images for 130 Lakes From The Western Lakes Region, Sand Hills, Nebraska. For Dillings, School Island, and Tree Claim, data from May 14, 1975, were eliminated because the lakes were not on the image. One data point in 1978 was eliminated from Island lake because the lake was drained to manage game fish population.

\begin{tabular}{|c|c|c|c|c|c|c|}
\hline \multirow[b]{2}{*}{ Lake } & \multicolumn{2}{|c|}{ UTM Coordinates } & \multirow{2}{*}{$\begin{array}{c}\text { Maximum } \\
\text { Area }\end{array}$} & \multirow{2}{*}{$\begin{array}{c}\text { Minimum } \\
\text { Area }\end{array}$} & \multirow{2}{*}{$\begin{array}{c}\text { Average } \\
\text { Area }\end{array}$} & \multirow{2}{*}{$\begin{array}{l}\text { Coefficient } \\
\text { of Variation }\end{array}$} \\
\hline & Easting & Northing & & & & \\
\hline \multicolumn{7}{|c|}{ Sheridan County (cont'd.) } \\
\hline Williamson & 719809 & 4665121 & 136 & 5 & 105 & 0.2422 \\
\hline Cody & 707461 & 4665724 & 74 & 17 & 51 & 0.2550 \\
\hline “P” & 699057 & 4665907 & 74 & $<1.5$ & 46 & 0.4295 \\
\hline Simondson & 708346 & 4666230 & 165 & 25 & 114 & 0.2879 \\
\hline Dennis 2 & 714871 & 4666862 & 79 & 40 & 62 & 0.1249 \\
\hline Jess & 699402 & 4666897 & 40 & $<1.5$ & 21 & 0.4392 \\
\hline “Q" & 699954 & 4667572 & 100 & $<1.5$ & 59 & 0.3259 \\
\hline Snow & 710115 & 4667999 & 299 & 180 & 266 & 0.0752 \\
\hline “R” & 700443 & 4668281 & 63 & $<1.5$ & 29 & 0.4748 \\
\hline Tin Can & 726642 & 4668426 & 123 & 9 & 80 & 0.1910 \\
\hline “AB" & 718999 & 4669729 & 190 & 63 & 115 & 0.3160 \\
\hline Wickson & 698771 & 4670053 & 170 & $<1.5$ & 125 & 0.2755 \\
\hline O'Brien & 723751 & 4671728 & 190 & 321 & 06 & 0.3635 \\
\hline White & 718653 & 4671892 & 120 & 22 & 75 & 0.2095 \\
\hline T Briggs & 704764 & 4672159 & 37 & $<1.5$ & 25 & 0.3396 \\
\hline "X" & 710401 & 4672511 & 79 & $<1.5$ & 50 & 0.2796 \\
\hline "AC" & 705323 & 4673223 & 72 & $<1.5$ & 47 & 0.3792 \\
\hline “W” & 713203 & 4673873 & 150 & 25 & 77 & 0.3188 \\
\hline Tree Claim & 699290 & 4674070 & 165 & 0 & 110 & 0.4111 \\
\hline Bennet S & 700783 & 4674509 & 86 & $<1.5$ & 56 & 0.3688 \\
\hline “S” & 702094 & 4674536 & 62 & $<1.5$ & 39 & 0.4288 \\
\hline Bennett N & 700063 & 4675027 & 134 & $<1.5$ & 88 & 0.3130 \\
\hline “ $\mathrm{Y}^{\prime \prime}$ & 717143 & 4675095 & 196 & $<1.5$ & 85 & 0.4400 \\
\hline Wilkinson & 701540 & 4675618 & 80 & $<1.5$ & 28 & 0.7555 \\
\hline Peter Long & 708506 & 4676954 & 387 & 14 & 271 & 0.3131 \\
\hline “Z” & 716871 & 4677132 & 99 & 45 & 71 & 0.1757 \\
\hline School Island & 700745 & 4677895 & 109 & $<1.5$ & 51 & 0.6724 \\
\hline Wilkinson 2 & 703808 & 4678046 & 117 & $<1.5$ & 61 & 0.5543 \\
\hline “AA" & 717608 & 4678923 & 139 & $<1.5$ & 23 & 1.8599 \\
\hline “U” & 701128 & 4680464 & 68 & $<1.5$ & 37 & 0.5021 \\
\hline “V" & 708242 & 4680566 & 228 & $<1.5$ & 135 & 0.3561 \\
\hline Dillings & 699698 & 4681024 & 80 & 15 & 60 & 0.1487 \\
\hline Goose 2 & 705944 & 4681501 & 69 & 5 & 48 & 0.2266 \\
\hline Diamond & 708156 & 4684246 & 398 & 239 & 312 & 0.1056 \\
\hline Skunk & 704279 & 4684429 & 99 & 17 & 68 & 0.2286 \\
\hline Albrecht & 706441 & 4685405 & 119 & $<1.5$ & 48 & 0.7439 \\
\hline
\end{tabular}

